\title{
THE KOREAN ADAM: YI HYOSEOK AND WALT WHITMAN
}

\author{
Steven D. Capener
}

YI HYoseoK (1907-1942) was one of the major Korean writers of his time, producing over two hundred works of poetry and prose. His popularity continues to this day: his works, which are included in almost every Korean best-twenty list of the last fifty years, are present in all authoritative anthologies and are taught as part of the governmentdesigned high school curriculum. ${ }^{1}$ Yi took his literary cues from the West more proactively than many of his contemporaries. He was especially influenced by the Miltonian trope of the loss of paradise and the Whitmanian version of redemption. It is in this context that I want to examine how these influences manifest themselves in Yi Hyoseok's literary consciousness, focusing in particular on how Walt Whitman's literary persona in Leaves of Grass appears in and shapes one of Yi's major pieces of short fiction.

In 1910, Korea became a colony of the Japanese Empire, thereby losing its independence. However, at the same time, Korea, as a colonial subject, began to be flooded by the same forces of modernity that had been rapidly transforming Japan since the beginning of the Meiji Restoration (1868). One of these imports was the formation of a "modern" Korean literature following on the heels of similar developments in Japan. By the mid-to-late 1930s, when Yi Hyoseok was at his most prolific, Korean literature written according to Western literary conventions was only in its third decade.

Yi's brand of literary modernism took on an eclectic flair that even to this day is difficult for critics to pin down. His use of a variety of themes, including a pronounced lyricism, a powerful - even graphicsexuality, an urbane cosmopolitanism, and a unique, verse-like prose style seemed to baffle later critics in their attempts to categorize him as both a writer and a person. In an 1937 essay titled "My School Days" published in Yosung [Women] magazine, Yi talks about some of his literary influences. In addition to mentioning specific writers (including Shelly, Yeats, and Whitman), he gives two other pieces of information that provide insight into his literary world. First, Yi describes himself as being initially attracted to poetry, a strong influence on his burgeoning literary self-awareness. Second, Yi describes absorbing both romantic 
and realistic literature, going even further to suggest that these two things can and, in fact, must co-exist in art. For Yi:

Literature grew out of a dialectic process between poetry and prose, and art was founded in the nexus where reality and dreams meet. Even when the apex of realism is reached, perhaps unknowingly the dream world is therein incorporated and this is not only essential to humanity but also may be the essence of art. ${ }^{2}$

It is clear, then, that Yi took inspiration for some of his prose from poetry. The most obvious examples of such poetic influence are the many references one can find in his work to Milton's Paradise Lost. Yi had written his graduation thesis on John Milton and subsequently made extensive use of the Miltonic archetype of the loss of paradise and the quest for redemption in his two completed full-length novels, Hwabun [Pollen, 1938] and Byeokgong Muhan [Endless Blue Sky, 1940]. His use of the loss (and recovery) of paradise motif is subversive of Milton in both the Blakean sense (the earth - and not heaven-is figured as paradise) and the Whitmanian sense-the Adamic protagonist seeks to recover/create a new paradise he has never known, having committed no original sin and suffered no loss. ${ }^{3}$

According to one source, Yi first came into contact with Whitman while in high school. Yi attended the best high school in Seoul, one that prepared students for entrance to the Imperial University. Here he immersed himself in a comprehensive poetry reader published in Japan, which included, in addition to Whitman, Heine and Goethe. ${ }^{4}$ Later, as a student of the English Literature Department of Gyeongseong Imperial University, he no doubt came into further contact with Whitman's work in the course of his studies. Whitman was being translated piecemeal into Korean beginning around $1920 .{ }^{5}$ In addition, there were occasional pieces on Whitman published in Seoul literary journals in the 1920s. ${ }^{6}$ In 1928, Leaves of Grass was published in Japan in the original English but with an extremely detailed Japanese language page-by-page explication of each poem (including bibliographic cross references to works of criticism in English, French, and German) by Takeshi Funahashi, a professor of English literature at Doshinsha University in Tokyo. This speaks to the level of interest in, and the sophistication of, Whitmanrelated studies in Japanese universities, which included Gyeongseong Imperial in Seoul. ${ }^{7}$ It is highly likely that Yi came into contact with Funahashi's publication of Leaves of Grass and its attendant interpretations.

Whitman's influence on Yi's literature is most pronounced in one of Yi's short stories written later in his career. The work provides a fascinating insight into how Yi read Whitman and subsequently appropriated aspects of both Whitman's literary idiom as well as his literary persona, that of the Adamic/Christ-like dispenser of redemption and 
democratic egalitarianism. The story is titled "Leaves of Grass" and subtitled "To have the poet Walt Whitman is to have happiness for mankind." The appropriation of Whitman's title is interesting in and of itself; however, the subtitle is even more intriguing. The story is a thinly-disguised autobiographical account of a love affair that Yi himself was engaged in after the death of his wife, and the protagonist is an undisguised manifestation of the author. The structure and plot of the story, the use of the title of Whitman's poem (literally translated into Korean: Pulib), and the editorializing subtitle all serve to strengthen the sense of association between the autobiographical protagonist of the story and Whitman.

"Leaves of Grass" was one of Yi's last works of fiction, published in 1942 shortly before the author's untimely death at the age of thirtyfive. At the time, Yi was a professor of English at Soongshil Technical College in Pyongyang, what is now Kim Il Sung University. He had lost his wife to disease several years before and his health had started to falter the previous year. He was, at the time, romantically involved with a well-known singer named Wang Subok, who had studied music in Japan. Their relationship was the source of much gossip, as Wang was rumored to have had an active love life even before meeting Yi.

In Yi's short story, Junbo, the protagonist, is in love with a woman named Shil. The plot, such as it is, is basically a discussion of the difficulties the two are facing in overcoming the personal and societal obstacles to their love. What makes this story unique, though, is Yi's high level of identification with, and indeed appropriation of, Whitman's poetic persona. In the story, Junbo not only reads large sections of Whitman's poetry to Shil, he in fact appropriates some of Whitman's literary projects, including his democratic leveling of the sexes, while becoming a Christ-like vessel of redemption. The first two-thirds of the thirty-three page story, one of Yi's longest, deals mostly with the challenges the two face as a result of Shil's past and the rampant rumors that circulate about her. Junbo is not immune to doubt and, after Shil's "confession" of her past dalliances, he admits, through the voice of the third-person narrator, that he will need passion and courage to deal with the situation.

Enter Whitman. In Yi's story, Whitman serves as the "old courageteacher," as Allen Ginsberg would later describe the poet in "A Supermarket in California." On the simplest level, Whitman's poetry provides Junbo the courage to accept Shil despite her past. But this is neither the only nor even the most remarkable aspect of Yi's use of Whitman. Yi actually channels Whitman through Junbo's appropriation of the poet's persona at its most Christ-like to absolve Shil and promise her redemption. 
In the course of discussing their troubles, Junbo proposes that they read some poetry for its soothing effects. While perusing his collection of poetry, Junbo gives us the following reasons for his selection of Whitman:

How about some Whitman? I like him for different reasons than those I like Yeats for. $\mathrm{He}$ is not only the poet of the people, but also the poet of all mankind. He will be remembered as second only to Jesus Christ. When I read him, my courage soars and my hope is restored. ${ }^{8}$

Junbo then goes on to read four pieces of Whitman's poetry, all translated into Korean by (we can assume) Yi himself. One is a verse from deep within "Song of Myself": "I am the poet of the woman the same as the man, / And I say it is as great to be a woman as to be a man, / And I say there is nothing greater than the mother of men."9

Junbo also reads "When I Peruse the Conquer'd Flame" to Shil, but most important to our discussion is the first poem that he recites. After associating Whitman with Christ, Junbo sits in a chair and prepares to read; Shil kneels at his feet as if in supplication, her hands on his knees and her head resting in his lap. Junbo then reads "To a Common Prostitute" without mentioning its title or quoting its first line:

Not till the sun excludes you do I exclude you,

Not till the waters refuse to glisten for you and the leaves to rustle for you, do my words refuse to glisten and rustle for you.

My girl I appoint you with an appointment, and I charge you that you make preparation to be worthy to meet me,

And I charge you that you be patient and perfect till I come.

Till then I salute you with a significant look that you do not forget me. $(L G, 387)$

By giving us this image of Junbo reading Whitman's poem of absolution and redemption to a "fallen" woman sitting at his feet in an attitude of reverence, Yi recreates the scene in the Book of Luke in which Christ absolves the prostitute (or sinful woman) who kneels in front of him to wash his feet. ${ }^{10}$ This association with the story in Luke (and/or John) is further strengthened when, upon hearing this poem, Shil sheds emotional tears of happiness. She remains with her head buried in Junbo's lap, and, when Junbo finishes reading, he sees she is crying just as the sinful woman in the Gospel of Luke is said to have cried at Christ's feet. As he finishes reading "To a Common Prostitute," Shil exclaims: "Marvelous! Wonderful! I feel as if he wrote those words for me." Following this, Junbo places one hand on Shil's head and makes a pronouncement: "To have Whitman is to have happiness for all mankind. I wish I could read Whitman to all those gossiping about us in the streets" (217). Shil, with tears in her eyes, replies: 
Is there anything in his [Whitman's] eyes that is base, or ugly, or beneath him? All he beholds is beautiful, equal, and worthy of love. He is as benevolent as Christ and as all-embracing as the ocean. (217)

She then goes on to say that sitting at Junbo's feet and hearing Whitman's poetry will probably turn out to be the happiest moment of her life.

It is in this way that Junbo is able, through the agency of Whitman's poetry and persona, to assume the role of a surrogate Christ and bring redemption to Shil. What has occurred here is a manifold act of identification. Yi has created Junbo in his own image; Junbo then assumes the voice of Whitman, who has taken on the mantle of Christ the redeemer, ultimately allowing Yi himself to personify the savior. But why?

The only critical treatment of Whitman's presence in this story (that I have been able to find) is by Yu Jongho, a prominent critic of Korean literature with a background in English literature. Yu addresses Yi's use of Whitman in a very short piece on "Leaves of Grass" which argues that Whitman is brought into the story as the "romantic poet who praises eternal, unchanging love." Yu goes on to suggest that Yi utilizes Whitman's poetry to "calm Shil's fears and, perhaps, help Junbo convince himself" (of what Yu doesn't say). ${ }^{11}$ These assertions are not a bad start but they do not go far enough.

Here we must again refer to the highly autobiographical nature of this story. Yi was, we can safely assume, experiencing the same events in real life as Junbo does in the story. This means he was wracked with similar doubts, misgivings, and apprehensions..$^{12}$ It also follows that his love interest, Wang Subok, was suffering from the various rumors and slander that were circulating. Yi's biographer, Yi Sangok, postulates that, "after clearly establishing that Junbo is, in fact, [Yi]," the author "uses Junbo to say some things he himself wants to say." Using Junbo as his mouthpiece, Yi writes:

I will teach people, through my actions and not my words, the following lessons: how different the truth is from rumor, that love is a free choice, and that happiness depends on the will of those involved and not the recriminations of the people around them. ${ }^{13}$

Yi Sangok cites the passage above as evidence "Yi is using Junbo" to declare "his intention to carry on his love affair with Wang Subok in spite of the malicious talk surrounding them."

Having made that decision, Yi must now deal with both his misgivings (as seen in Junbo's assertion that he will need courage) and Wang Subok's suffering. By adopting Whitman's poetic metaphysics and becoming the messenger of ameliorating love and the vehicle of absolution, both of Yi's problems are at least addressed if not solved. 
And so, in subtitling his story "To have the poet Walt Whitman is to have happiness for mankind," Yi seems to be saying that "to have (and perhaps to become) the poet Walt Whitman is to have a way to happiness for myself."

Yi's "Leaves of Grass," then, is an illuminating example of how American literature was being grafted onto the still young Korean literary sapling. For scholars of Whitman, it is a fascinating instance of his poetics being appropriated by a non-Western writer, not only as a source of personal courage but also an antidote to problems encountered in a non-Western tradition: in this case the hyper status-conscious rigidity and hereditary class structure of Korea's Confucian tradition. In his repudiation of the class-conscious, nationalist (and anti-Western) rhetoric of the day, Yi echoes Whitman's transcendental appeal to a common humanity.

Seoul Women's University

\section{NOTES}

1 Unfortunately, Yi's works are under-translated into English considering his status as a writer. Only one of his short stories, "When the Buckwheat Blooms," is currently available in translation. See $A$ Ready-Made Life: Early Masters of Modern Korean Fiction, selected and translated by Kim Chong-un and Bruce Fulton (Honolulu: University of Hawai'i Press, 1998), 133-142.

2 Yi Hyoseok, "Naui Suopshidae" ["My College Days"], Yi Hyosoek feonjib [The Collected Works of Yi Hyoseok] (Seoul: Changmi sa, 2003), 7:160.

3 For an in-depth discussion of this topic see Steven D. Capener, "Paradise Found: Recovery and Redemption in Yi Hyoseok's Later Literature," Seoul Fournal of Korean Studies, 22 (June 2009), 87-90.

4 Gwon Jeongho, Yi Hyoseok munhak yeongu [A Study on the Literature of Yi Hyoseok] (Seoul: Wolin, 2003), 35.

5 Kim Byeongcheol, Seoyang munhak beonyeoknonja yeonpyo [Record of the Translation of Western Literature by Year] (Seoul: Eulsa Munwhasa, 1978).

6 Two such examples are as follows: Kim Anseo, "Shidan sanchaek" ["A Perusal of the Poetry Scene"], Foseon Mundan [foseon Literary Scene], (March, 1925). This is a very brief introduction to Whitman and several other Korean poets. Yi Unsang, "Shiin Hwitumaen lon" ["The Poet Whitman"], foseon Mundan [Foseon Literary Scene], (May 1925). This is a more comprehensive treatment (twelve pages) of Whitman's life, poetics, and poetry.

7 Funahashi Takeshi, Leaves of Grass (Tokyo: Kenkyusha, 1928).

8 Yi Hyoseok, "Pulib" ["Leaves of Grass"], The Collected Works of Yi Hyoseok (Seoul: Changmisa, 2003), 3:216. All translations of Yi's writings in this essay are my own. 
9 All passages of Whitman's poetry (that Yi translated into Korean) are reprinted here as they appear in Walt Whitman, Leaves of Grass: Comprehensive Reader's Edition, ed. Sculley Bradley and Harold W. Blodgett (New York: New York University Press, 1965), 48. Hereafter, $L G$.

10 Of course, both Whitman and Yi might have been thinking of the adulterous woman in the Book of John who is given absolution by Christ. In the edition of Leaves of Grass published in Japan in 1928 and edited by Funahashi Takeshi, the explication of "To a Common Prostitute" states that it is the story of forgiveness of a fallen woman, likely a prostitute, and that it is based on the "beautiful little idyll of the New Testament," possibly the story in John, 8:1-2. Funahashi, Leaves of Grass, 312-313.

11 Yu Jongho, Yi Hyoseok (Seoul: Jihaksa, 1985), 223.

12 In fact, there are numerous references in essays written by Yi's friends and colleagues that testify to the fact that $\mathrm{Yi}$ was experiencing the very events he described in "Leaves of Grass". See, for example, Han Sucheol, "Hui! Yi Hyoseok" ["Oh! Yi Hyoseok"], fogwang (1942), 7.

13 Yi Sangok, Yi Hyoseokui salmgwa munhak [Yi Hyoseok's Life and Literature] (Seoul: Jibmundang, 2004), 335-336. 